\title{
DESIGN OF WOODWOOD MACHINERY USING ROUTER
}

\author{
Rusdiyantoro*) \\ ${ }^{*}$ Industrial Engineering Department, Faculty ofIndustrial Technology \\ University of PGRI Adi Buana Surabaya \\ Email :rusdiyantoro@unipasby.ac.id
}

\begin{abstract}
The art of carving or engraving ornament is the image with certain parts, usually concave, convex or flat, patterned and has a motive. Sculpture can be formed pictures on wood, acrylic, or other materials. In making this product a design researcher perform analysis or potential problems that occur with experiments in doing a good carving designs are done by hand or automatically The definition is a prototype assessment products through on eor more dimensions of concern. In the process of making utensils or equipment requires some work benchesare wont to do in the workshop in general. After the finished product made testing will be conducted experiments in order to know the performance of the products. Testing is carried out using a sample design engraving. The concept of design and manufacture of the products is a bigpart of engineering Activities. This activity starts with he obtained perceptions about human needs, which are then followed by the concept, then designing, developing and refining the product, ending with the manufacture of the product
\end{abstract}

Keyword: Sculpting Technique, Prototype, Designing

\section{INTRODUCTION}

The art of carving or carving is an ornate picture with certain parts, usually concave, convex, or flat with pattern and motif. Sudarmono and Sukijo (1979: 4) suggested that carving or engraving is scratching or sculpting letters and drawings on wood or metal to produce embossed and concave or flat forms in accordance with the drawing of the plan. In contrast to modern carving, traditional sculpture was born not only as a work of art and a goal to art, but very closely tied to the problems that grow and develop in traditional societies. Thus this traditional carving art can initially be born due to offerings to the ancestors in accordance with their respective beliefs. In this study will discuss the merger between the concept of how to work manual techniques and the use of a machine. Ditoko machine tool widely available also carved machines that use the principle of CNC. But the problem is here that is related to the price dibanderol for a CNC carving machine is very expensive. The process is to make a carving design does not take a long time because it is programmed but, it takes a long time to complete the program.

If analyzed in more detail, a carving machine based on CNC or a purely manual using the hands together has a very basic weakness. Not necessarily a clever artist or understand the programming language in a machine, so the carpenter concluded that the way manualah more effective. Likewise with a programmer or operator for CNC engraving machine, not necessarily can make a manual engraving by hand as well as artisans ukir.In this study, researchers will try to make a design tool to carve or carve the merger between the engraving machine by carving manually " hand carving ". Merging machine and manual system according to the researcher will be very effective to do carving work let alone to produce scale many. Researchers will use more affordable materials but make them as strong and as good as possible to produce good and precise carvings. 


\section{LITERATURE REVIEW}

\subsection{Traditional Carving Art}

Carving art is an artificial or an artificial form of natural beauty, but the shape has been made new decorative style as the fruit of the creator's creations, taste, and art. Carving art tends to be stylized or stylized from natural

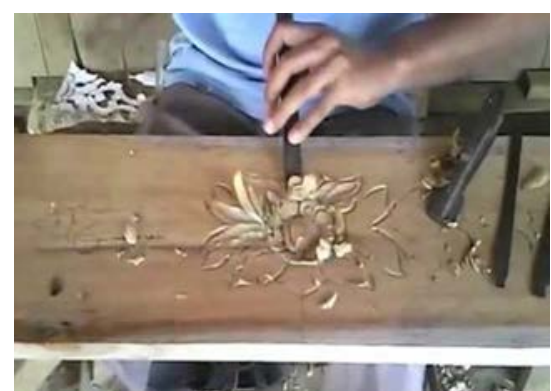

objects, so characteristic characteristic personality or even characterized the regional as a reflection of artists and regions. The object of nature is universal, while the replicas are personal and distinctively local, so they are different from other areas (Irfa'ina Rohana Salma: 2014).

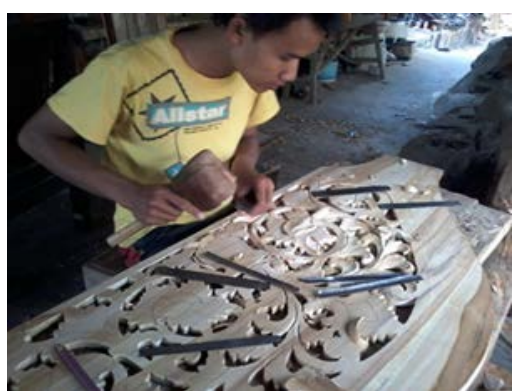

Figure 1. Traditional Engraving Activities

\subsection{Modern Carving Art}

The sculpture is present in a more sophisticated form without the use of a direct hand to do it but by using a CNC (Computer Numerecally Control) carving machine. Changing the process of engraving manually or conventionally becomes the process of carving automatically. In today's technology become the center of attention in every corner of the world including Indonesia. Continuing developments require humans to think intelligently in developing things in all areas.

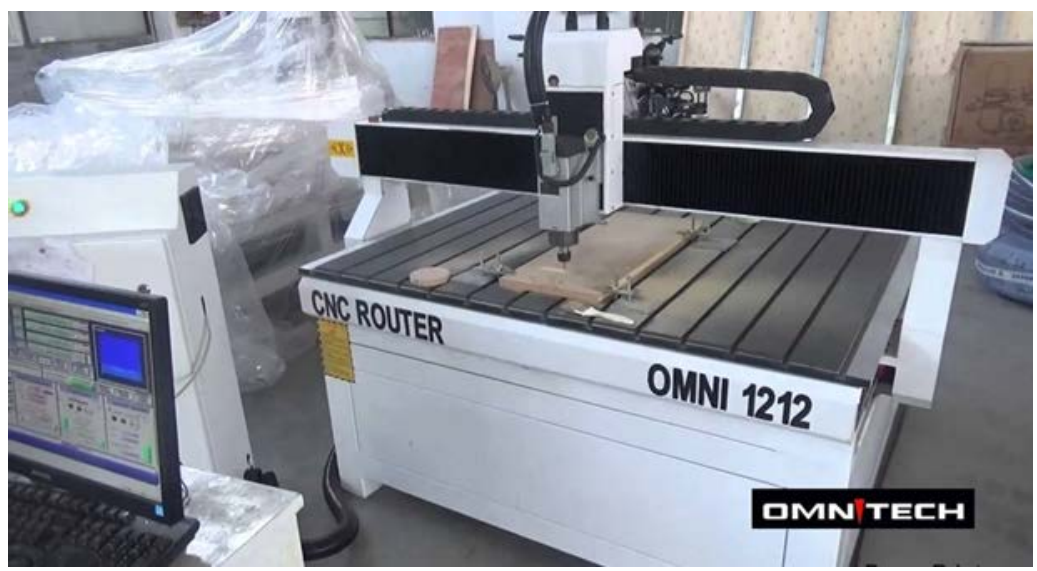

Figure 2. CNC Engraving Machine

The actual engraving activity done by using the artist's hand is no longer a problem in making an engraving design. Moreover, using a carving machine that is interested in its exotic carvings but has no artistic soul or art background to make it easier to work on. The presence of this machine with its sophistication can automatically do carving design faster.
The working principle of this machine is almost the same as miling machine or CNC miling that can stir in three axsis with $\mathrm{X}$ axis, $\mathrm{Y}$ axis, and $\mathrm{Z}$ axis with a combination of mechanical system, electrical, and computer peripheral. Mechanical system used to move the machine which need high precision to assemble. Electrical system as the successor or voltage source on the machine in order to 


\section{TiBuana}

Journal of applied Industrial Engineering-University of PGRI Adi Buana

p-ISSN 2622-2027

$e$-ISSN 2622-2035

move. Computer device as a command or control of the engraving machine controller

This automatic carving machine can not be separated from the computer device which is the main system. Operating a CNC machine in this way requires the expertise to translate the workpiece image into a numerical code. Work drawings are usually created manually or using CAD software (Computer AidedDesign). Along with the development of technology in the field of computers, has been available software containing CAD graphics applications and can translate the work image into a numerical code. The software is CAM (Computer AidedManufacturing). This programming fills in the code language that has been standardized by ISO, in CNC is known by code "G code". This code language serves as a means of communication between the machine and its users and to provide data information on the machine that is understood (Retno Tri Wahyuni, DjokoPurwanto, TriAriefSardjonoenulis: 2013).

\subsubsection{Designing}

According to Ginting (2013) in (yusufyudha: 2013), the concept of product design and manufacture is a big part of engineering activities. This activity begins with the acquisition of perceptions about human needs, which then followed by the concept, then the design, development and refinement of products, ending with the manufacture of products. Product is an engineering object whose existence in the world is the result of engineering work, that is the result of design, manufacture and other related engineering activities.

Based on the design requirements that have been clearly stated, then can be developed a solution to problem solving. Determination of the design solution must be

\section{METHODOLOGY}

\subsection{Product Design}

In making a design of this product the researcher performs an analysis or potential problems that occur in working on a carving

design either done by hand or automatic. All from the engineer or researcher. In the translation needs, researchers see the opportunity to anticipate the emergence of a complaint that is by designing a working tool in the form of a carving machine. To design the engraving machine, the researchers adopted and modified the working principle of manual carving by hand and carving machine with CNC technology. The idea will be used as an input about things that want to be replaced or done a good addition to the components of a complete engraving machine as a consideration in the design.

\subsubsection{Prototype}

The definition of a prototype is "an appraisal of a product through one or more of the dimensions of concern" (Ulrich and Eppinger, 2001). (Based on this definition, any form that shows at least one product aspect of interest to the product development team can be displayed as a prototype. The prototype can be classified into two dimensions, the first dimension dividing the prototype into two namely the physical prototype and the analytic prototype.

- Physical Prototype is a real object made to estimate the product. The aspects of the product that the development team is interested in are actually made into an object for testing and experimentation.

- The analytic prototype is the opposite of a physical prototype that merely displays unreal products, usually in mathematical form. Examples of analytic prototypes include computer simulations, computer models, three dimensional or twodimensional geometry, and systems of writing equations on computer papers. 
data will be collected and identified kelemahanya. Based on the analysis can be formulated or known product design specifications to be made, including: 1) the material of the maker, 2) the prime mover, 3 ) the parts of the design, 4) the working principle. To know the conceptual design of this manual carving machine will be done sketch designs made with the help of computer devices and manufacture of manual carving products.

In the manufacturing process requires some tools or work benches are usually done dibengkel in general. After the finished product is made will be tested in order to know the performance of the product. In the process of testing this product also sees conventional hand carving process which is done by hand and automatically using CNC based machine. This process is carried out not only as a basis for development but also to know the prototype success rate will be made. A product revision needs to be done if in the process of designing up to testing there are some drawbacks that need to be added or changed and require further arrangement according to the analysis and interpretation of test results.

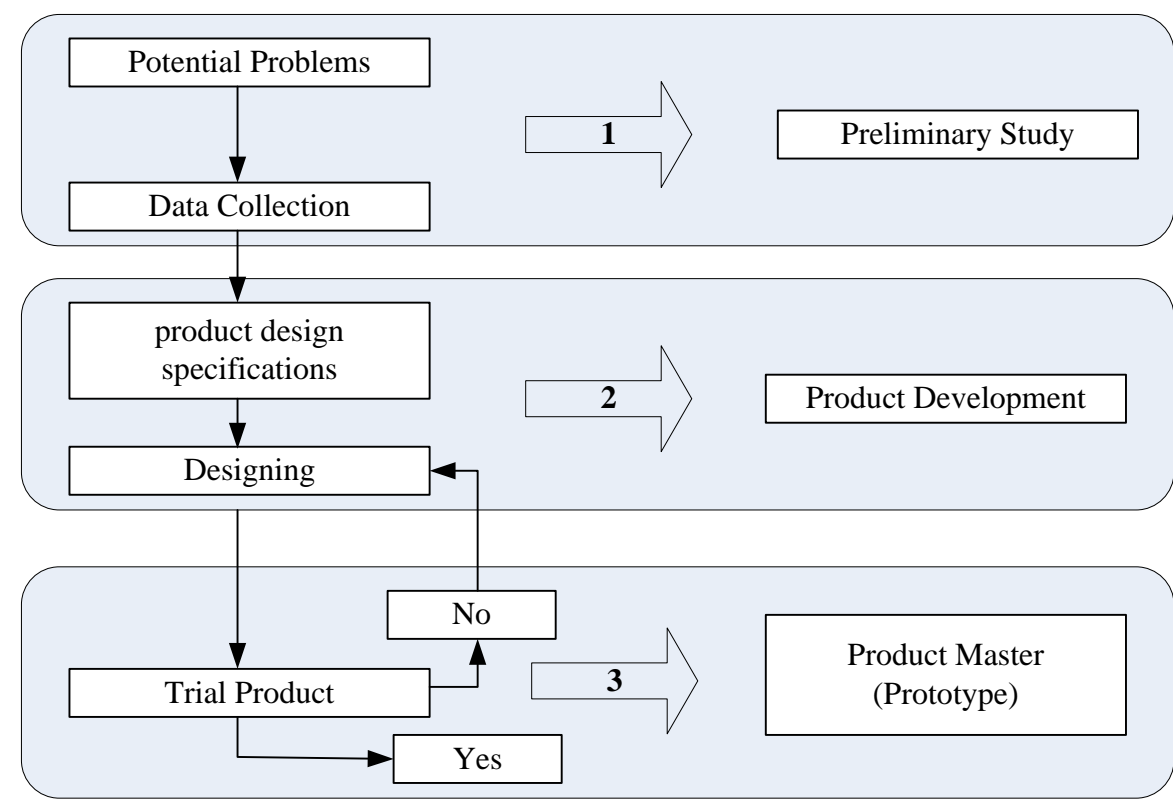

Figure 3. Flowchart

\subsection{Product Test}

Trial usage is done with the aim to know the operational feasibility of developed products. The experiment was carried out as a research sample involving experimental test material.

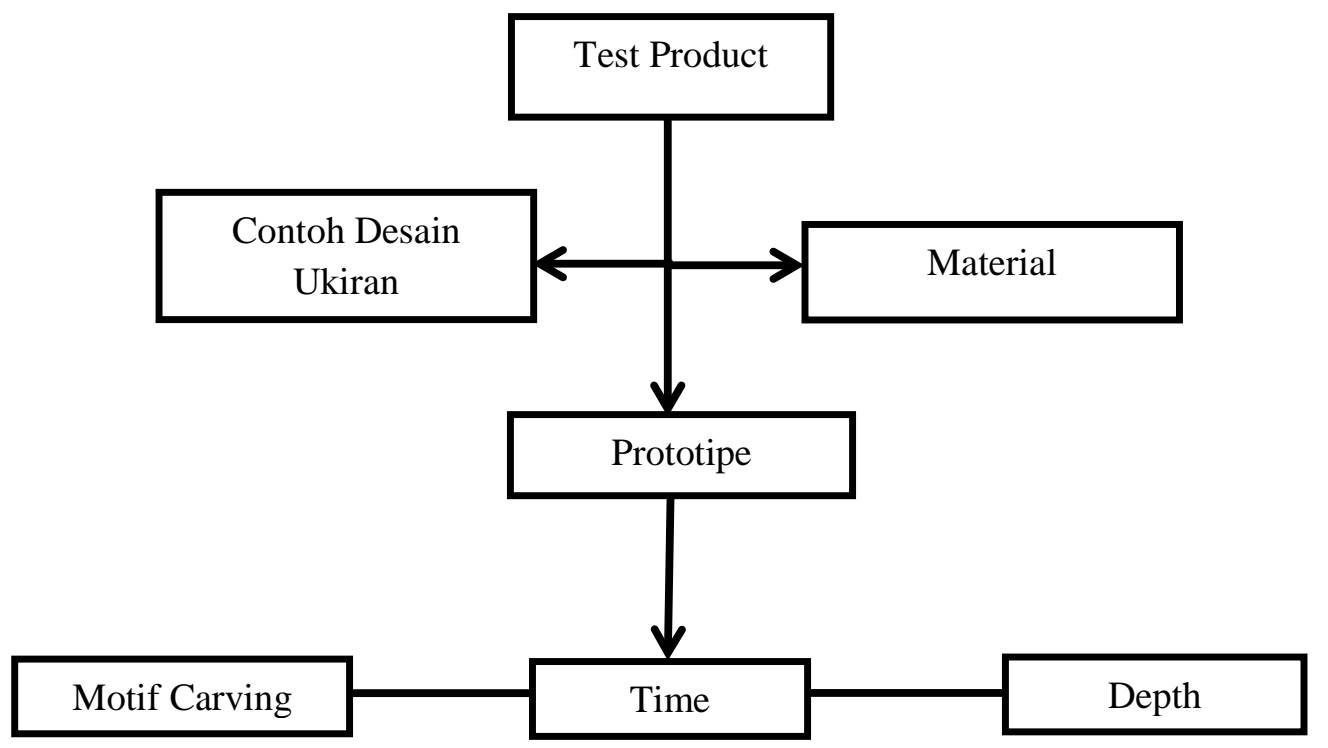




\section{TiBuana}

Journal of applied Industrial Engineering-University of PGRI Adi Buana

Figure 4 Carving Testing Comparison

Material testing in this research as an experimental material using wood. The material will be tested with the same engraving design. With the same carving design will make it easier for researchers to retrieve data from the test results.

\subsection{Data analysis method}

To determine the level of product success resulting in research this development then the researchers take data from the test results with examples of carving design patterns. From these results will raise a conclusion whether the product made successfully or not with various provisions

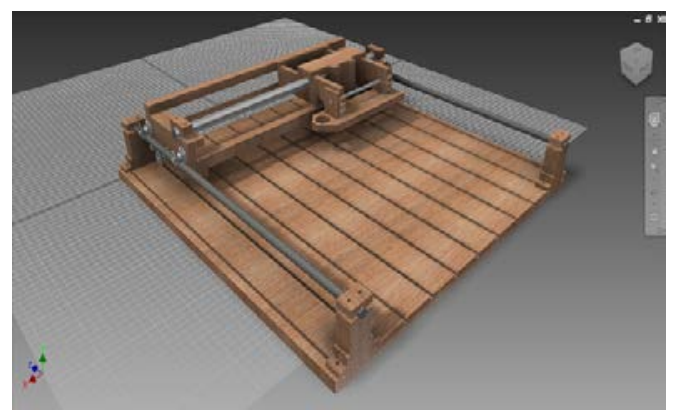

according to testing. Documenting activities done for shooting, movement or pattern of engraving activity.

\section{RESULTS AND DISCUSSION}

\subsection{Design of Engraving Machine}

In preparing the design plan for this final project, the researcher performs the drawing sketchh with the help of Autodesk Inventor computer software to facilitate the early stages of carving machine. The main material maker is $75 \%$ made of wood / press, only a few parts made of iron material.

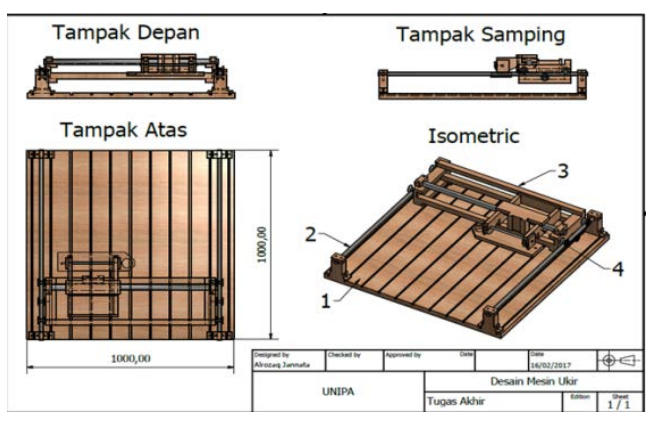

Figure 5 Engineering Drawing and 3 Dimensional Engraving Machine

\subsection{Carving Machine Working Principles}

The working principle of the design of this machine is almost the same as the CNC machine that can move in three axsis with $X$ axis, $\mathrm{Y}$ axis, and $\mathrm{Z}$ axis. There is a difference in pengerjaanya, if CNC using programs with CAM technology (Computer AidedManufacturing), the machine design peneilti use hand to work with copier system. If there are variations of different ukuiran motifs, to equate with the motif must replace the router bit according to the pattern according to the size of the motif.

\subsection{Engraving Machine Specification 4.3.1. Carrying Machine Tool}

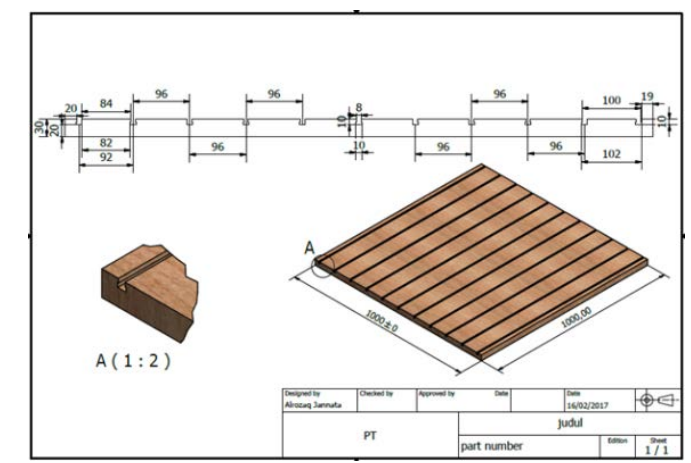


TiBuana

Journal of applied Industrial Engineering-University of PGRI AdiBuana

Figure 6 Technical drawing and 3 dimensions of carving pedestal

Alas carving machine is made of MDF type wood board material that has a size of $1 \times 1$ meter. Each gap is made like a track path to clamp the workpiece to be engraved and locked using a bolt.

\subsubsection{Rail Engraving Machine}
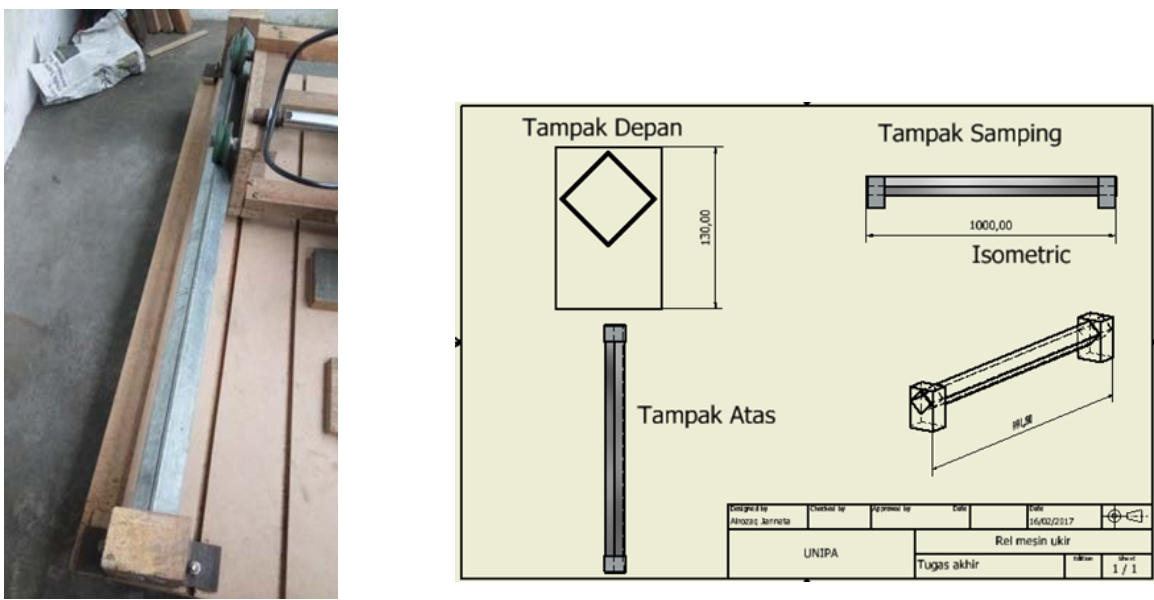

Figure 7 Technical drawing and 3 dimensional rail engraving machine

The picture above is a rail than the carved engine design results that have been made. The

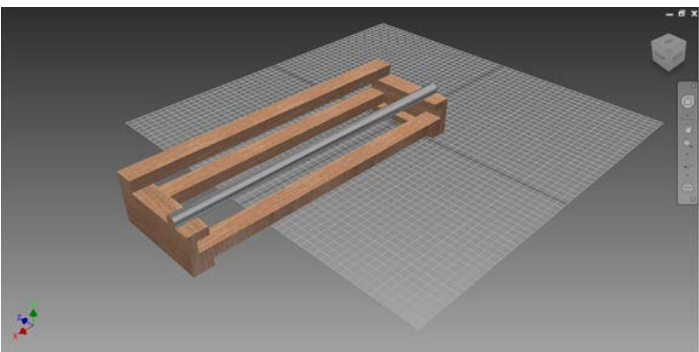

rail is a track running on the $\mathrm{Y}$ axis with the help of the $\mathrm{V}$ wheel on the rails.

\subsubsection{Head Movers}

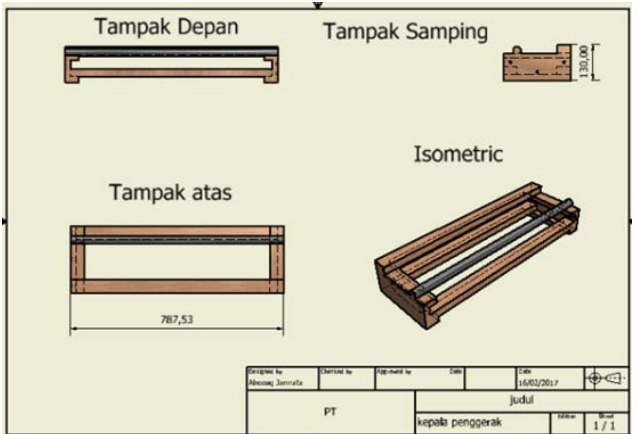

Figure 8 Technical drawing and 3 dimensional car drive engine head

The picture above is part of the main driving head that runs $\mathrm{X}$-axis. This section is also the main head or holder with the help of linear shafts and bearings. 


\section{TiBuana}

\subsubsection{Head of Main}
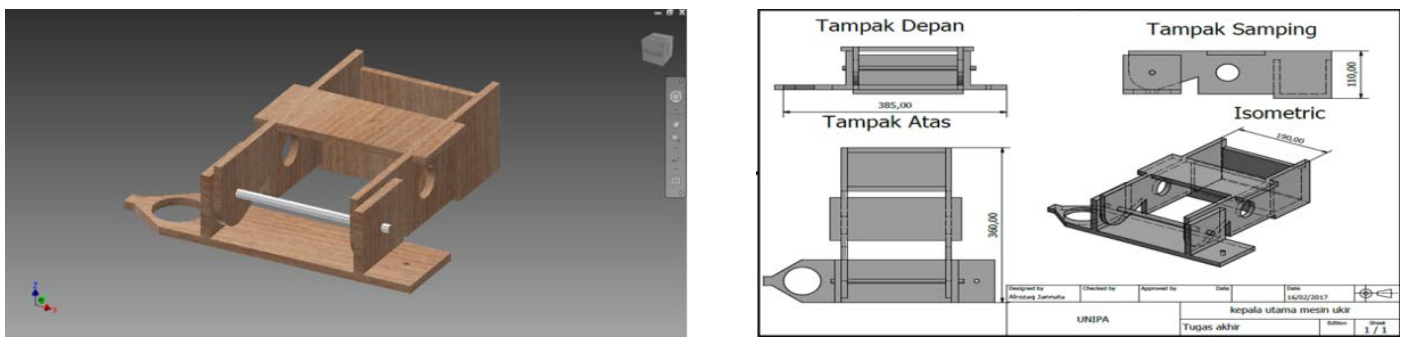

Figure 9 Technical drawing and 3 dimensions of the main head of the engraving machine

This section is the main head of the engraving machine to be made. Beside there is a home router or trimer as the main driving force that will form an engraving. In the main head also serves as the $\mathrm{Z}$ axis in pengerjaanya the movement up and down. In order to move vertically the researchers used a linear bearing LM 25 UU with a $25 \mathrm{~mm}$ shaft. The box behind it is a place for lead or preloat that serves as the main head balancer. In addition there is also a stylus that serves sebgai followers copier image to be made.

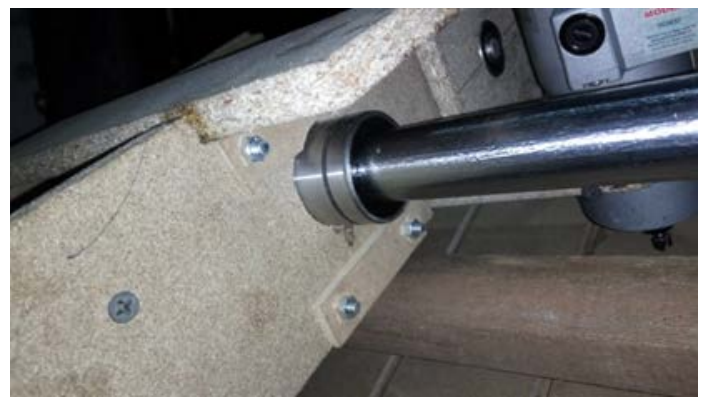

Figure 10 Linear Bearing Image

The main head also serves as a motorcycle handler or trimer which is used as the main driver for carving work. This motor has a power of $30,000 \mathrm{rpm}$ has a voltage of $220 \mathrm{~V}$
AC and $440 \mathrm{~W}$. Capacity size of $10 \mathrm{~mm}$ colled bits and profile bits used as needed or follow the design drawings to be made.

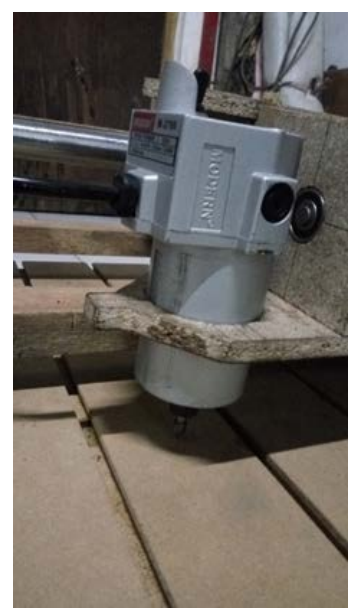

Figure 11 Router or Trimmer Image 


\subsection{Analysis Of Results}

In accordance with the formulation and research objectives that have been expressed in the above then the researchers will make a prototype carving machine that is more timeefficient and easier pengunaanya. By utilizing wood as the main ingredient for making carving machine. It is said to be easy because it eliminates the programs used on automatic machines, this machine can be used by all circles both the layman and the experienced who like the art of sculpture. Of course, equipped with other materials to be able to make this carving machine works well and according to what is expected by using duplicating system. The first step the researchers tested the design tool first with the basis of various motifs carving.

Table 1 Carving Motive Test

\begin{tabular}{llll}
\hline Number & \multicolumn{1}{c}{ MotiveCarving } & \multicolumn{1}{c}{ Time } & Depth \\
\hline 1. & Staright $50 \mathrm{~mm}$ & 1 minute 22 seconds & $2 \mathrm{~mm}$ \\
2. & Semi Circle & 2 minute 39 seconds & $2 \mathrm{~mm}$ \\
3. & CircleØ $80 \mathrm{~mm}$ & 5 minute 36 seconds & $2 \mathrm{~mm}$ \\
4 & CircleØ $28 \mathrm{~mm}$ & 2 minute 23 seconds & $2 \mathrm{~mm}$ \\
& Total Time & 11 minute 20 seconds & \\
\hline
\end{tabular}

From the table above data can be seen that the basis of the work of the engine designer engraving can work according to the pattern specified. The carving motif is the basis for making the full engraving design. The basic test uses a $5 \mathrm{~mm}$ router bit size.

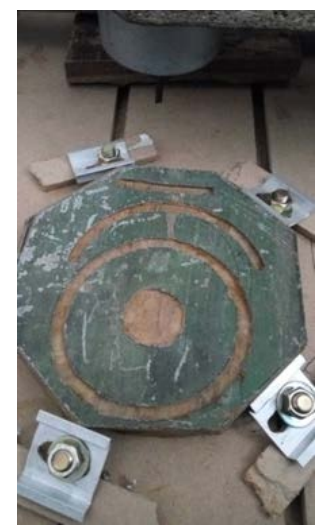

Figure 12 Draw the results of the basic test engraving machine

The results of these tests show that the wood carving machine using a draft designer researchers can work well. With copier system that carried this machine will make it easier in the work of a carved drawing design. This engraving machine is very easy to use especially to make carving designs in large quantities. If you see conventional engraving

\section{Conclusion}

- The timing for engraving results from the engine design of the researcher is more activity by hand, carving engine designer results more efficient for the quality of processing time. Wearing the handrouter as the prime mover and router bits that can be changed as desired, this machine can make various motifs of carving design.

Based on the results of research and discussion in this study can be concluded as follows: efficient and faster by using copier system. 
- The cost of the researcher is not too expensive to make a carving machine

\section{References}

1. Jaedun, A. (2011). Metodologi Penelitian Eksperimen, Makalah Pelatihan Penulisan Artikel Ilmiah, 1-11

2. Nofrial. (2014). Ukiran Akar Kayu Pulau Betung Jambi Menuju Industri Kreatif. Ekspresi Seni Jurnal Ilmu Pengetahuan dan Karya Seni,16(1), 65-85.

3. Prasetyo, Y.Y. (2014). Perancangan Alat Ukir Tiga Dimensi Dengan metode Ergonomi, Skripsi Teknik Industri FTUniversitas Wijaya Surabaya.

4. Sari, S.C., Jannati, R.P. (2015).

$\begin{array}{lr}\text { Jenis \& } & \text { Paradigma } \\ \text { Metodologi } & \text { Penelitian } \\ \text { Eksperimen, Makalah Magister } \\ \text { Pendidikan Matematika FKIP- } \\ \text { Universitas } \\ \text { Palembang,1-36. }\end{array}$
design.

5. Salma, I.R. (2014). Seni Ukir Tradisional Sebagi Sumber Inspirasi Penciptaan Batik Khas Baturaja. Jurnal Dinamika Kerajinan dan Batik, 31(2), 75-84.

6. Wahyuni, R.T., Purwanto, D., Sardjononulis, T.A. (2013). Aplikasi Rekonstruksi 3 Deimensi Pada Proses Pemahatan menggunakan CNC. Jurnal Elektro dan Komputer, 1(2), 180-190.

7. Yaqin, A. (2013). Pitutur Luhur Sebagai Teks Kaligrafi Jawa Dalam Karya Ukir Kayu.Arty: Jurnal of Visual Art, 2(1), 112. 